\title{
29 Response of Quinoa to High Salinity under Arid Conditions
}

\author{
Mohammad Shahid and Sumitha Thushar
}

\section{CONTENTS}

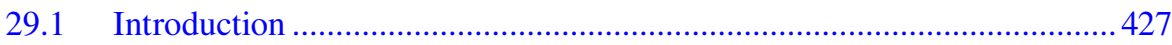

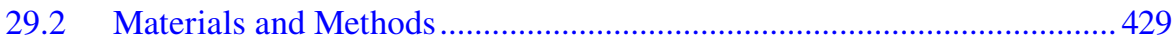

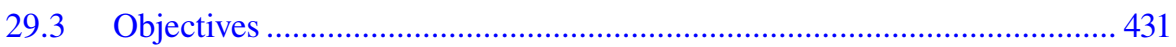

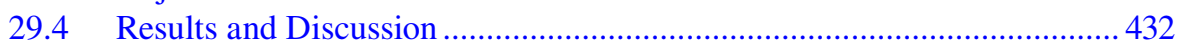

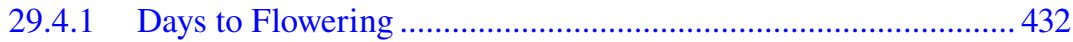

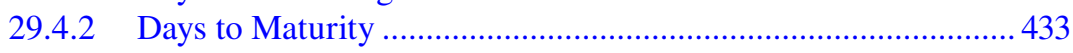

29.4.3 Plant Height................................................................................ 433

29.4.4 Number of Primary Branches per Plant...................................... 434

29.4.5 Number of Panicles per Plant................................................ 435

29.4.6 Length of Main Panicle.......................................................... 436

29.4.7 Plant Dry Weight per Square Meter......................................... 436

29.4.8 Seed Weight per Square Meter.............................................. 437

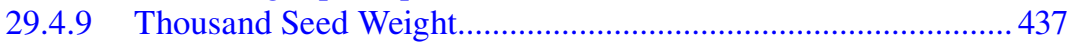

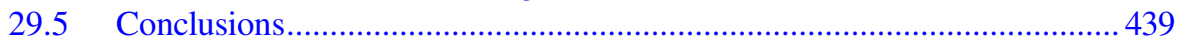

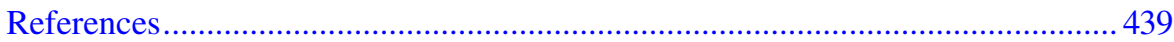

\subsection{INTRODUCTION}

Quinoa (Chenopodium quinoa Willd.) is a pseudo-cereal crop, which is herbaceous and matures within 3-6 months. It belongs to the Amaranthaceae family that also includes prominent crops like beet and spinach. The cultivation of the plant started around 7,000 years ago (Kolata, 2009) after domestication of wild populations of Chenopodium quinoa (Pickersgill, 2007) in the Andes mountain range of South America. Quinoa is a highly nutritive crop as its grains contain all 9 essential amino acids, which few other crops possess. It has a low Glycine Index (GI) making it suitable for diabetics, but is rich in fiber, protein (14-20\%), B vitamins and important minerals like iron, magnesium, potassium and manganese (Vaughn and Geissler, 2009). It also contains good carbohydrates and important fatty acids, making it a good food for human consumption (Koziol, 1992; Ranhotra et al., 1993; RepoCarrasco et al., 2003). It is an ideal food for health-conscious people as well as for children in the third world countries where wholesome diets may not be available. 
Though the typical quinoa grain yield is $0.4-0.9 \mathrm{t} / \mathrm{ha}$, yields of up to $2-3.5 \mathrm{t} / \mathrm{ha}$ have been possible with improved agricultural practices (Jacobsen et al., 1994). High yields have been obtained from different parts of the world including Denmark (Jacobsen et al., 1994), France (L'Avenir Agricole, 2015), Pakistan (Iqbal et al., 2018) and India (Singh, 2018). Quinoa can also be used as a fodder crop. Average quinoa forage yields of around $10 \mathrm{t} \mathrm{DM/ha} \mathrm{have} \mathrm{been} \mathrm{recorded} \mathrm{(Taváres} \mathrm{et} \mathrm{al.,} \mathrm{1995).}$

Quinoa grows nicely in well-drained sandy soils of low nutritional status and with a $\mathrm{pH}$ range of 6.0-8.5. It is a facultative halophytic crop (Jacobsen et al., 2005; Koyro et al., 2008; Adolf et al., 2013) which makes it suited to marginal lands with salinity problems. Field experiments at low and high salinity have shown that certain quinoa cultivars can give good yields at high salinity (Iqbal et al., 2019). Salinity is increasing in different parts of the world and has affected about $7 \%$ of arable land (Panta et al., 2014), which is responsible for a substantial decline in agricultural production in those areas. For cultivation in salt-affected agricultural lands, crops tolerant to salinity are needed.

Salt-tolerant plants have three different strategies to cope with high salinity: tolerance against osmotic stress, exclusion of ions $\left(\mathrm{Na}^{+}\right.$or $\left.\mathrm{Cl}^{-}\right)$from tissues, and tolerance to accumulated ions (Munns and Tester, 2008). Considerable variation in salinity tolerance exists amongst food crops. For example, within the major cereals, rice (Oryza sativa L.) has lowest tolerance, while barley (Hordeum vulgare L.) is the most salt-tolerant crop (Munns and Tester, 2008). The difference in salt-tolerance among dicotyledonous plants is greater. Forty-four percent of species in the Amaranthaceae are salt-tolerant in nature, which is the highest percentage among plant families (Flowers et al., 1986).

In saline conditions, Gómez-Pando et al. (2010) observed a sizeable difference amongst 200 quinoa genotypes for germination rate. Highly saline water $(0.4 \mathrm{M}$ $\mathrm{NaCl}$ ) decreased the germination of quinoa seed by $\sim 60 \%$ and decreased the fresh weight of germinating seeds by $60 \%$, but it did not affect the dry weight of germinating seeds (Prado et al., 2000). $\mathrm{NaCl}$ reduces the fructose and glucose but increases the sucrose contents in quinoa seedlings. The increase in sucrose may be an indication of osmotic adaptation and/or a reduction in metabolic activities under highly saline conditions ( Prado et al., 2000). Many quinoa accessions can tolerate salinities at the seedling stage of up to $150 \mathrm{mM} \mathrm{NaCl}$ (Ruiz-Carrasco et al., 2011) while some can resist salinities of more than seawater (Jacobsen et al., 2003).

There is no correlation between the salinity-tolerance of quinoa at the seed germination stage and during subsequent plant growth (Adolf et al., 2012). The genotypes that perform poorly at germination may fare well at later stages and vice versa. In a study by Hariadi et al. (2011), best quinoa plant growth was observed at $10-20 \mathrm{dS} / \mathrm{m}$, while a decrease in yield was noted at $15 \mathrm{dS} / \mathrm{m}$ and above during other experiments (Jacobsen et al., 2001; 2003). In another study, the threshold salinity (above which yield was decreased) for a quinoa variety was found to be $11 \mathrm{dS} / \mathrm{m}$ (Wilson et al., 2002).

One of the main causes of decreased growth due to salinity is ion excess of sodium $\left(\mathrm{Na}^{+}\right)$, particularly in stems and leaves of plants. $\mathrm{Na}^{+}$exclusion is a key factor in maintaining the normal metabolism in plant cells. The ion exclusion is facilitated by a $\mathrm{Na}^{+} / \mathrm{H}^{+}$exchanger located at the plasma membrane (Blumwald et al., 2000), 
which is encoded by the salt overly sensitive (SOS1) gene (Hasegawa et al., 2000; Qiu et al., 2002; Mullan et al., 2007). The accumulation of sodium ions in the cytosol is prevented by a tonoplast $\mathrm{Na}^{+} / \mathrm{H}^{+}$exchanger $\mathrm{NHX}$ which shifts $\mathrm{Na}^{+}$into the vacuole (Apse et al., 1999; Shabala and Mackay, 2011). In quinoa, two of the SOS1 genes (cqSOS1A and cqSOS1B) have been found with homologies to the genes of other halophytic species (Maughan et al., 2009). Under non-saline conditions, the expression of cqSOS1A and cqSOS1B was about 4 times stronger in roots than in leaves. On the other hand, exposure to salinity ( $45 \mathrm{dS} / \mathrm{m})$ led to over expression of these genes in leaves compared to root tissues (Maughan et al., 2009).

Various studies have been carried out at the International Center for Biosaline Agriculture (ICBA), Dubai, UAE to examine the salt-tolerance and adaptability of quinoa to the region. In one investigation, several quinoa genotypes were assessed for yield-related characteristics to examine their performance in hot environment and sandy soils (Rao and Shahid, 2012). In another study, different cultivars of the crop were grown in different regions of the world to explore their adaptation and tolerance against salinity (Choukr-Allah et al., 2016). The present field experiment was carried out at high and low salinities, to find the salt-tolerance of 11 accessions of quinoa, at ICBA during the cropping season of 2018-19. This trial also included 5 quinoa varieties that had been developed by ICBA.

Djulis (Chenopodium formosanum Koidz.) like quinoa is a pseudo-cereal crop native to Taiwan, and is also known as Taiwanese quinoa. It is mostly grown as a leafy vegetable in its native land, but its seeds are highly nutritious as they are rich in protein and dietary fiber, and contain essential amino acids. The seeds also contain antioxidants and pigments making it a healthy food (Tsai et al., 2011). Studies have shown that its seed helps in protecting the skin against the harmful effects of ultraviolet radiation (Hong et al., 2016)

\subsection{MATERIALS AND METHODS}

The trials were carried out at the field research facilities of the ICBA Dubai, United Arab Emirates (N 25 05.847; E $055^{\circ} 23.464$ ), which is situated around $23 \mathrm{~km}$ from the Arabian Gulf, between October 2018 and April 2019.

The soils of the ICBA research area are relatively alkaline ( $\mathrm{pH} 8.2)$, porous $(45 \%$ porosity), calcareous $\left(55 \% \mathrm{CaCO}_{4}\right)$ and have a sandy texture $(98 \%$ fine sand, $1 \%$ silt and $1 \%$ clay). With a saturation percentage of 26 , the soil has extremely high drainage capacity. The saturated extract of the soil has an electrical conductivity $\left(\mathrm{EC}_{\mathrm{e}}\right)$ of $1.2 \mathrm{dS} / \mathrm{m}$. In accordance with soil classifications based on American Soil Taxonomy (Soil Survey Staff, 2010), the soil is Typic Torripsamments, hyperthermic and carbonatic (Shahid et al., 2009).

Before planting, compost was added to the sites selected for the field experiments at the rate of 40 tonnes per hectare $\left(\mathrm{t} \mathrm{ha}^{-1}\right)$. Urea (46-0-0) was applied at the rate of $40 \mathrm{~kg} \mathrm{ha}^{-1}$ after 4 weeks of seed germination, while NPK (20-20-20) was added at the rate of $30 \mathrm{~kg} \mathrm{ha}^{-1}$ after 4 weeks of urea application. Both the synthetic fertilizers were applied using a fertigation method.

Eleven quinoa cultivars and one djulis variety were selected for the field experiment (Table 29.1). Each set of the accessions was sown using a randomized complete 
TABLE 29.1

Eleven Different Accessions of Quinoa (1-11) and One Djulis Variety (12) Selected for the Yield Trials

$\begin{array}{llcl}\text { S.N. } & \text { Accessions } & \text { S.N. } & \text { Accessions } \\ 1 & \text { ICBA-Q1* } & 7 & \text { NSL-84449 } \\ 2 & \text { ICBA-Q2* } & 8 & \text { Ames-13215 } \\ 3 & \text { ICBA-Q3* } & 9 & \text { Puno } \\ 4 & \text { ICBA-Q4* } & 10 & \text { Titicaca } \\ 5 & \text { ICBA-Q5* } & 11 & \text { NSL-106399 } \\ 6 & \text { Ames-13757 } & 12 & \text { Zhang Li 3 } \\ \text { * Quinoa varieties developed at International Center for Biosaline } \\ \text { Agriculture (ICBA). } \\ \text { Zhang Li 3 is a djulis variety developed in Taiwan. }\end{array}$

block design (RCBD) in three replications. There were two water salinity $\left(\mathrm{EC}_{\mathrm{w}}\right)$ treatments: low salinity $(0.3 \mathrm{dS} / \mathrm{m})$ and high salinity $(15 \mathrm{dS} / \mathrm{m})$. The high salinity treatment was started 2 weeks after planting.

The sowing was done in the $3^{\text {rd }}$ week of October. Each plot size was $1 \times 2 \mathrm{~m}$. The seeds were sown manually by dibbling 3-4 seeds into the soil to a depth of 1-2 cm close to the dripper. The plant to plant and row to row distance was $25 \mathrm{~cm}$. Once sowing was completed, the field was covered with acryl sheet to stop birds eating the planted seeds. After germination, only one seedling was kept at each spot. The field was covered with net at flowering to stop birds from eating seeds from the panicles (Figure 29.1).

Data on 9 agronomic and morphological traits (Table 29.2) were collected to determine the effect of salinity on the quinoa and djulis plants. For the traits, "days to flowering" and "days to maturity", the data were taken when half of the plants had

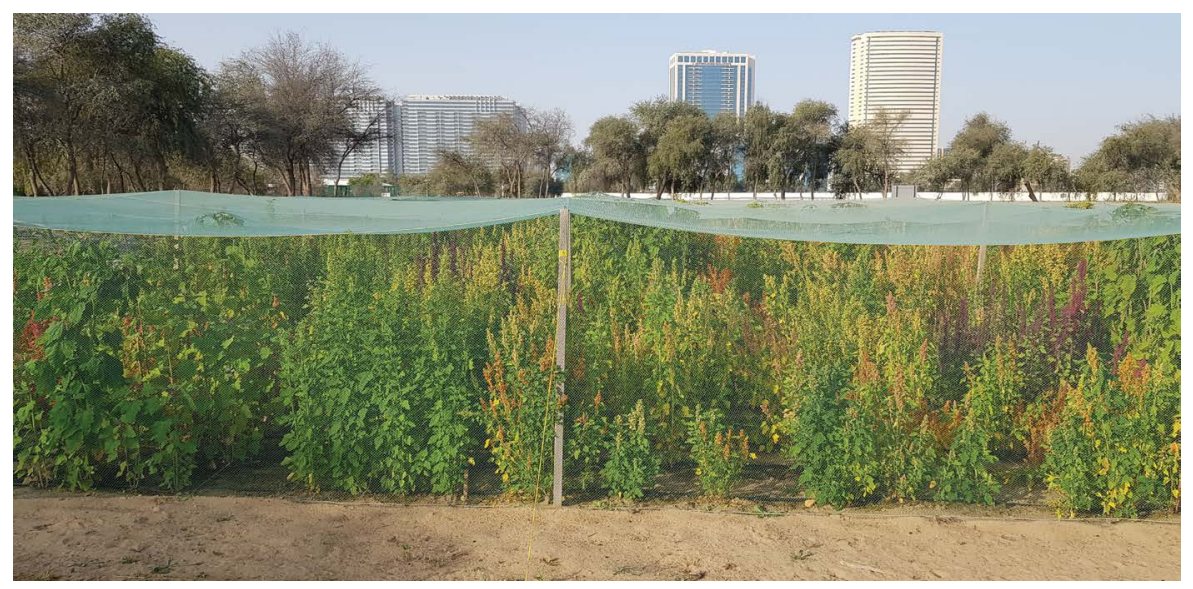

FIGURE 29.1 Quinoa yield trial at ICBA covered with nets to protect the seed from birds. 


$\begin{array}{ll}\text { TABLE } 29.2 & \\ \text { Different Agronomic and Morphological } \\ \text { Characteristics Studied in the Field Experiment } \\ \text { S.N. } & \text { Traits } \\ 1 & \text { Days to flowering } \\ 2 & \text { Days to maturity } \\ 3 & \text { Plant height } \\ 4 & \text { Number of primary branches per plant } \\ 5 & \text { Number of panicles per plant } \\ 6 & \text { Length of main panicle } \\ 7 & \text { Plant dry weight } \mathrm{m}^{-1} \\ 8 & \text { Seed weight } \mathrm{m}^{-1} \\ 9 & \text { Thousand seed weight }\end{array}$

flowered and matured, respectively. All other characteristics were studied after the plants had reached maturity. Before taking the plant dry weight, the plants were kept in a dryer at $40^{\circ} \mathrm{C}$ for 48 hours.

A drip irrigation system was used for the experiment with drippers at $25 \mathrm{~cm}$ distance, which was part of the Supervisory Control and Data Acquisition system. Irrigation was twice a day for 5 minutes each time. Water was released from each dripper at a rate of $4 \mathrm{~L} / \mathrm{h}$. The plots were irrigated daily for both the saline and non-saline treatments. The chemical properties of the irrigation waters are given in Table 29.3.

Data on temperature, relative humidity and precipitation at the experimental field were taken from the weather station at ICBA (Table 29.4).

\subsection{OBJECTIVES}

The field experiment had the following objectives:

- To understand the effect of salinity on different morphological and agronomic traits of quinoa under field conditions

- To see how saltwater affects yield and yield related characteristics of the different quinoa cultivars developed at ICBA and other parts of the world

- To select quinoa accessions suitable for cultivation in marginal lands with salinity problems around the world

TABLE 29.3

\section{Chemical Properties of the Irrigation Waters Used in the Field Experiment}

\begin{tabular}{lccccccccc} 
Water Treatment & $\mathbf{E C}(\mathbf{d} \mathbf{S} / \mathbf{m})$ & $\mathbf{p H}$ & \multicolumn{8}{c}{ Soluble Ions (meq/L) } \\
& & & $\mathrm{Cl}$ & $\mathrm{CO}_{3}$ & $\mathrm{HCO}_{3}$ & $\mathrm{SO}_{4}$ & $\mathrm{Na}$ & $\mathrm{K}$ & $\mathrm{Ca}+\mathrm{Mg}$ \\
low salinity & 0.30 & 7.87 & 3.0 & 0.00 & 1.32 & 0.0 & 2.0 & 0.06 & 1.6 \\
high salinity & 15.0 & 7.43 & 13.4 & 0.12 & 3.52 & 62.4 & 109 & 2.28 & 73.6 \\
\hline
\end{tabular}


TABLE 29.4

Temperature, Relative Humidity and Precipitation at the Experimental Field during the Cropping Season

\begin{tabular}{|c|c|c|c|c|c|c|c|}
\hline Year & Month & $\begin{array}{c}\text { Temperature } \\
\text { Mean }\left({ }^{\circ} \mathrm{C}\right)\end{array}$ & $\begin{array}{c}\text { Maximum } \\
\text { Temperature } \\
\text { Mean }\left({ }^{\circ} \mathbf{C}\right)\end{array}$ & $\begin{array}{c}\text { Minimum } \\
\text { Temperature } \\
\text { Mean }\left({ }^{\circ} \mathbf{C}\right)\end{array}$ & $\begin{array}{c}\text { Maximum } \\
\text { Relative } \\
\text { Humidity } \\
\text { Mean (\%) }\end{array}$ & $\begin{array}{c}\text { Minimum } \\
\text { Relative } \\
\text { Humidity } \\
\text { Mean (\%) }\end{array}$ & $\begin{array}{l}\text { Precipitation } \\
(\mathbf{m m})\end{array}$ \\
\hline 2018 & October & 28.8 & 36.9 & 21.7 & 74.9 & 20 & 0 \\
\hline 2018 & November & 23.0 & 30.1 & 16.3 & 75.5 & 26.2 & 0.2 \\
\hline 2018 & December & 18.3 & 25.8 & 11.4 & 80.0 & 29.8 & 0.3 \\
\hline 2019 & January & 16.8 & 24.4 & 10.0 & 86.2 & 28.3 & 25.2 \\
\hline 2019 & February & 21.5 & 29.1 & 14.9 & 77.3 & 22.1 & 19.8 \\
\hline 2019 & March & 20.2 & 28.0 & 13.3 & 76.7 & 19.2 & 0 \\
\hline 2019 & April & 27.2 & 34.8 & 20.4 & 71.9 & 17.7 & 0 \\
\hline 2019 & May & 32.6 & 40.5 & 24.7 & 57.8 & 13.9 & 0 \\
\hline
\end{tabular}

\subsection{RESULTS AND DISCUSSION}

\subsubsection{Days to Flowering}

Quinoa genotypes have shown variation in emergence of the inflorescence and flowering according to their place of origin (Bhargava et al., 2007; Curti et al., 2016; Sosa-Zuniga et al., 2017). Our experiment showed similar variation. The cultivars Titicaca and NSL106399 had the earliest flowering (after 49 days). Zhang Li 3 flowered after 99 days making it the latest in this category (Figure 29.2). On average, high salinity hastened days to flowering by 3 days. The djulis variety Zhang Li 3 flowered 9 days earlier due to high salinity. While working on two quinoa varieties at

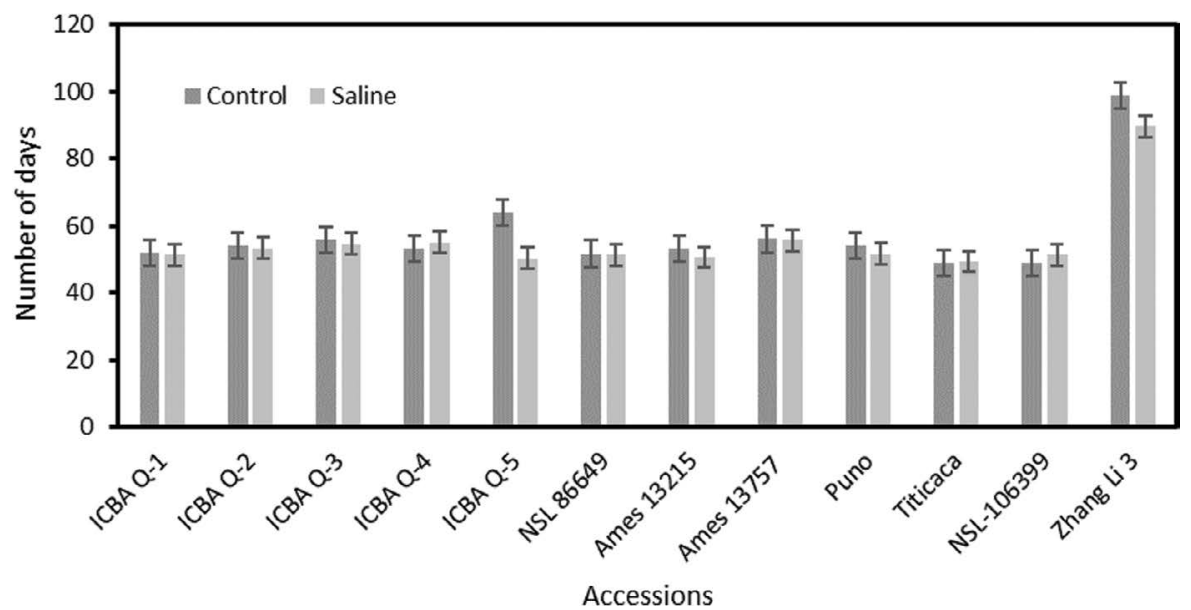

FIGURE 29.2 Days to flowering of quinoa and djulis accessions at low and high salinities. 


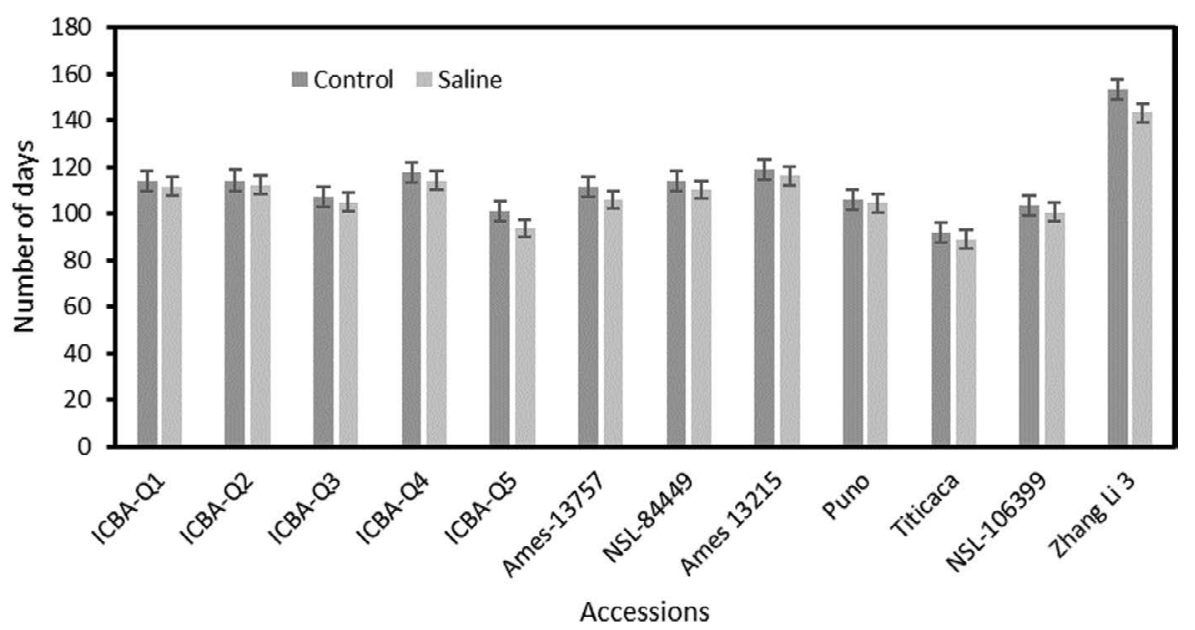

FIGURE 29.3 Days to maturity of quinoa and djulis accessions at low and high salinities.

4 different salinities, Algosaibi et al. (2017) found that high salinity hastened flowering by 4 to 8 days. The statistical analysis of the data shows a significant difference among the studied accessions.

\subsubsection{Days to Maturity}

Early maturity is a desirable trait for crops as it saves time and resources, especially, the precious irrigation water of farmers. Titicaca matured 92 days after planting making it the earliest of the 11 quinoa varieties studied (Figure 29.3). ICBA Q-5 (101 days) was the second earliest maturing variety. The djulis variety Zhang Li 3 took the longest period of time, maturing after 145 days. For quinoa growers who prefer early maturing varieties, Titicaca and ICBA would be ideal.

In control plots, the median maturity time for the quinoa varieties was 113 days, while irrigation with saline water decreased the maturity period by 5 days. Salinity reduced the days to maturity for all the planted accessions (Figure 29.3). Overall, a notable variation was observed for days to maturity amongst the cultivars using analysis of statistical data. Similar results were obtained by Algosaibi et al. (2017), working on quinoa genotypes under low and high salinities; in this work, high salinity treatment decreased the time to maturity by 27-35 days.

\subsubsection{Plant Height}

The quinoa plant can be used as a leafy vegetable (El-Naggar et al., 2018) as well as an alternative fodder for farm animals (van Schooten and Pinxterhuis, 2003). Quinoa leaves contains more protein than amaranth, spinach and moringa (Pathan et al., 2019), which makes it excellent vegetable and fodder. Tall plants will be better for both vegetable and fodder purposes as greater biomass can be expected for these. 


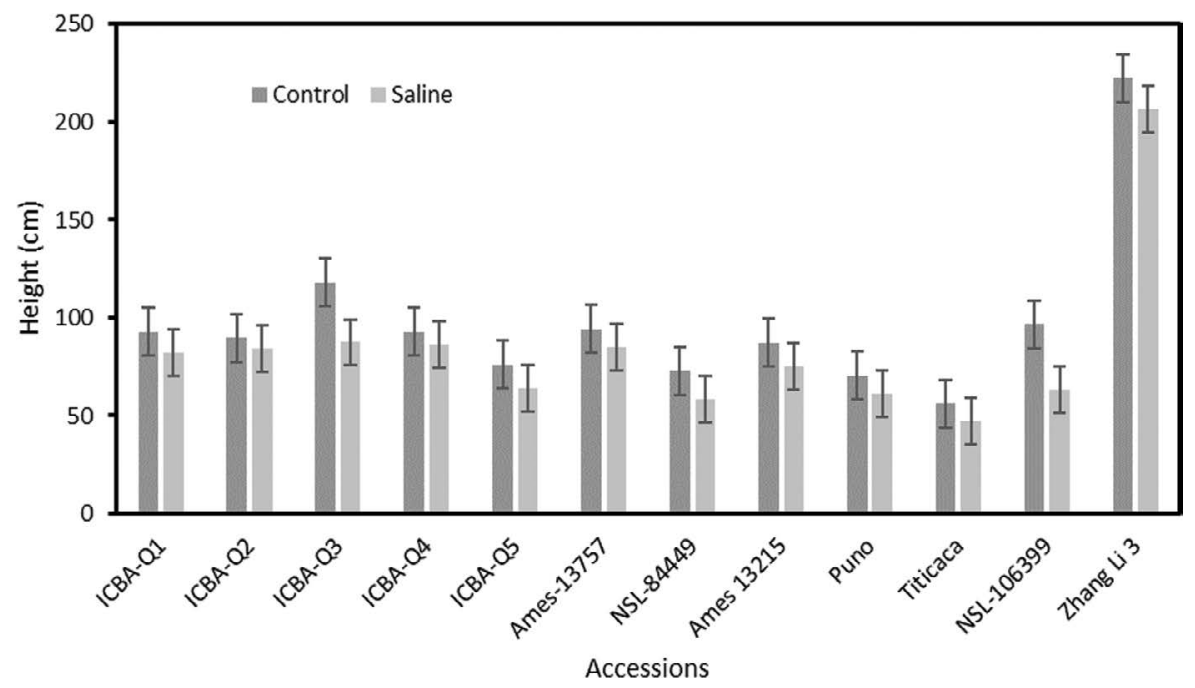

FIGURE 29.4 Plant heights of quinoa and djulis accessions at low and high salinities.

In our experiment, the greatest plant height was with the djulis variety Zhang Li $3(\sim 220 \mathrm{~cm})$ followed by ICBA Q-3 $(117 \mathrm{~cm})$, which had almost half of the height of the former accession. The shortest accession amongst the 12 accessions was Titicaca ( $\sim 56 \mathrm{~cm}$ tall) (Figure 29.4).

On average, use of saline water decreased plant height by $\sim 10 \mathrm{~cm}$. The most severely affected accession was NSL 106399, which lost $34 \%$ of its height due to high salinity; the least affected cultivar was ICBA Q-2, with only a $6 \%$ decrease (Figure 29.4). Negative effects of salinity on quinoa plant height has also been observed by Long (2016), Koyro et al. (2008) and Algosaibi et al. (2017). Highly saline water decreases the plant capability to absorb water from soil which effects its growth negatively.

\subsubsection{Number of Primary Branches per Plant}

Statistical analysis of the data revealed a significant difference in the number of primary branches per plant in the 12 genotypes (Figure 29.5). The lowest number of primary branches was in Zhang Li 3 (1.1); the second lowest was in NSL 106399 (2.1). The highest number of branches was in NSL 84449 (9.4) and Ames-13215 (6.3).

In response to high salinity, quinoa reduced the number of primary branches; the average decrease was $9 \%$. The greatest reduction in branches was with ICBA Q-1 ( $25 \%$ decrease), while Titicaca had no difference due to high salinity. Interestingly, Zhang Li 3 and Ames-13215 had an increase in number of branches due to irrigation with high saline water (Figure 29.5). Long (2016) also noted negative effects of high salinity on the number or branches in quinoa; their decline in the number of branches due to salinity was about $26 \%$. 


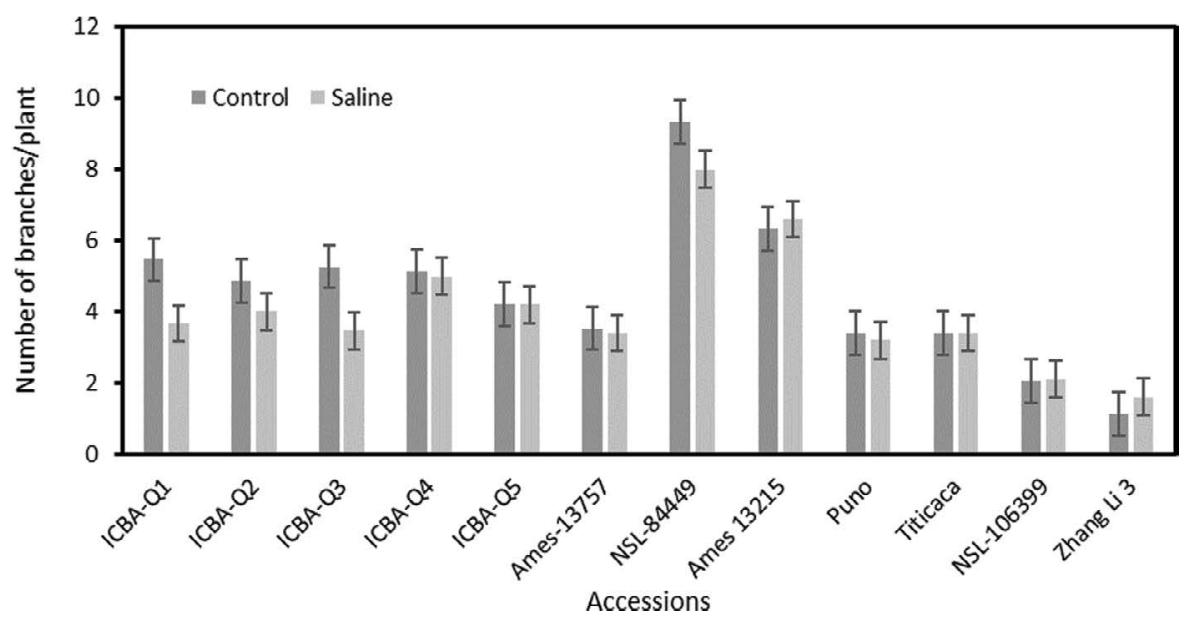

FIGURE 29.5 Number of branches per plant of quinoa and djulis accessions at low and high salinities.

\subsubsection{Number of Panicles per Plant}

The number of panicles per plant is related to grain yield. A larger number of panicles per plant may therefore indicate the prospect of better seed production in quinoa. The highest number of panicles per plant in our study were with NSL-84449 (9.3) and Ames-13215 (6.2). Djulis cultivar Zhang Li 3 had the lowest number of panicles (1.1) among the 12 studied quinoa cultivars (Figure 29.6).

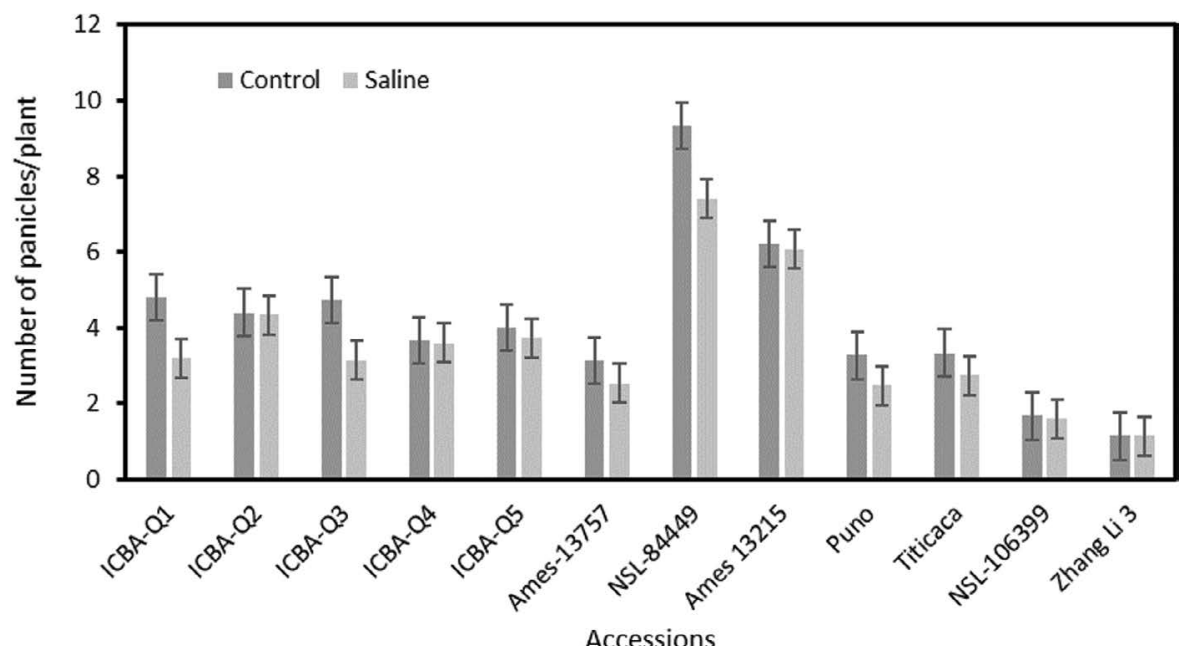

FIGURE 29.6 Number of panicles per plant of quinoa and djulis accessions at low and high salinities. 


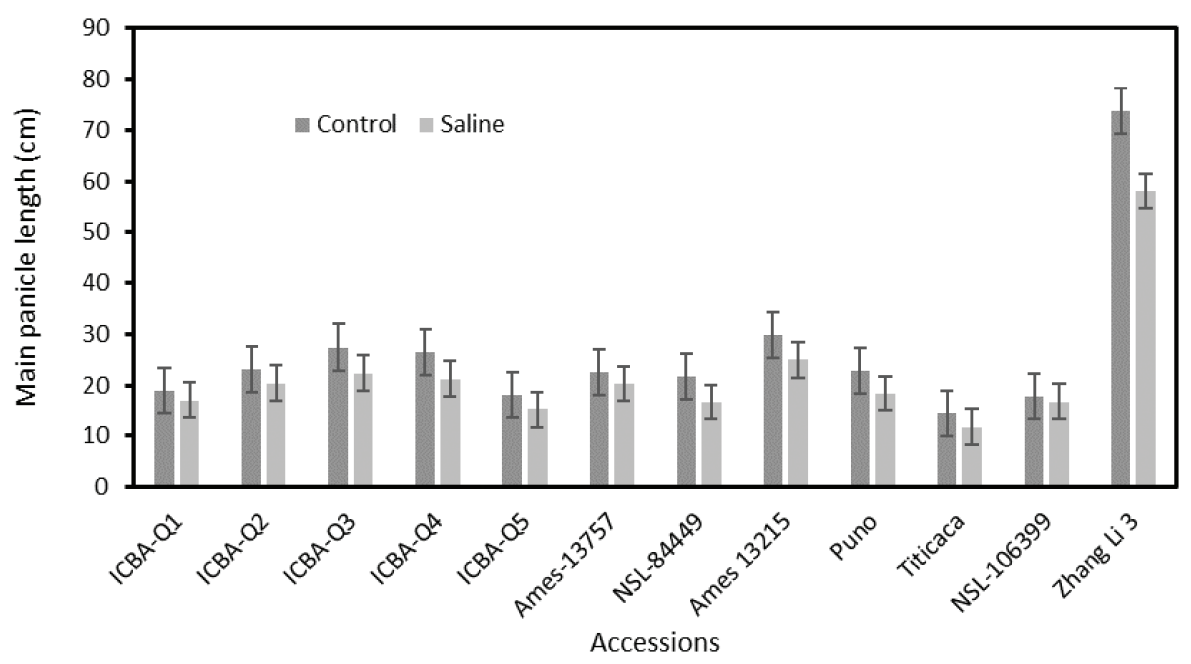

FIGURE 29.7 Panicle length of quinoa and djulis accessions at low and high salinities.

Irrigation with saline water decreased the panicle number in the quinoa plants by an average of $15 \%$. The most affected accessions were ICBA Q-1 and ICBA Q-3, which showed a $34 \%$ reduction in panicle number, while no effect of salinity was recorded with Zhang Li 3 (Figure 29.6).

\subsubsection{Length of Main Panicle}

Panicle size is directly related to the amount of seed it contains. Larger panicles contain more grain than smaller panicles. Zhang Li 3 had the longest panicle $(73 \mathrm{~cm})$ followed by Ames-13215 (30 cm). The shortest panicle was in variety Titicaca (14 cm) (Figure 29.7).

High salinity treatment reduced the panicle length in quinoa on average by $17 \%$. The negative effect was most obvious in djulis variety Zhang Li 3 which had a $21 \%$ decrease in panicle length (Figure 29.7). The same phenomenon was also observed by Long (2016) and Algosaibi et al. (2017) in quinoa, where reductions of $17 \%$ and $30 \%$ in panicle length was recoded respectively due to high saline water treatment.

\subsubsection{Plant Dry Weight per Square Meter}

Plant dry weight determines the fodder yield of a crop. Higher plant dry weight is a desirable trait for quinoa grown as a forage crop. Among the 12 studied cultivars, Zhang Li 3 had the heaviest plant dry weight $\left(1440 \mathrm{~g} \mathrm{~m}^{-2}\right)$, which was more than double that of Ames-13757 the second-best performing accession $\left(668 \mathrm{~g} \mathrm{~m}^{-2}\right)$. Because of its high vegetative production, Zhang Li 3 could be used as a fodder quinoa variety (Figure 29.8).

Overall, there was a $18 \%$ decrease in plant dry weight due to high salinity amongst the 12 accessions. NSL- 84449 with a $7 \%$ reduction was the least affected accession, 


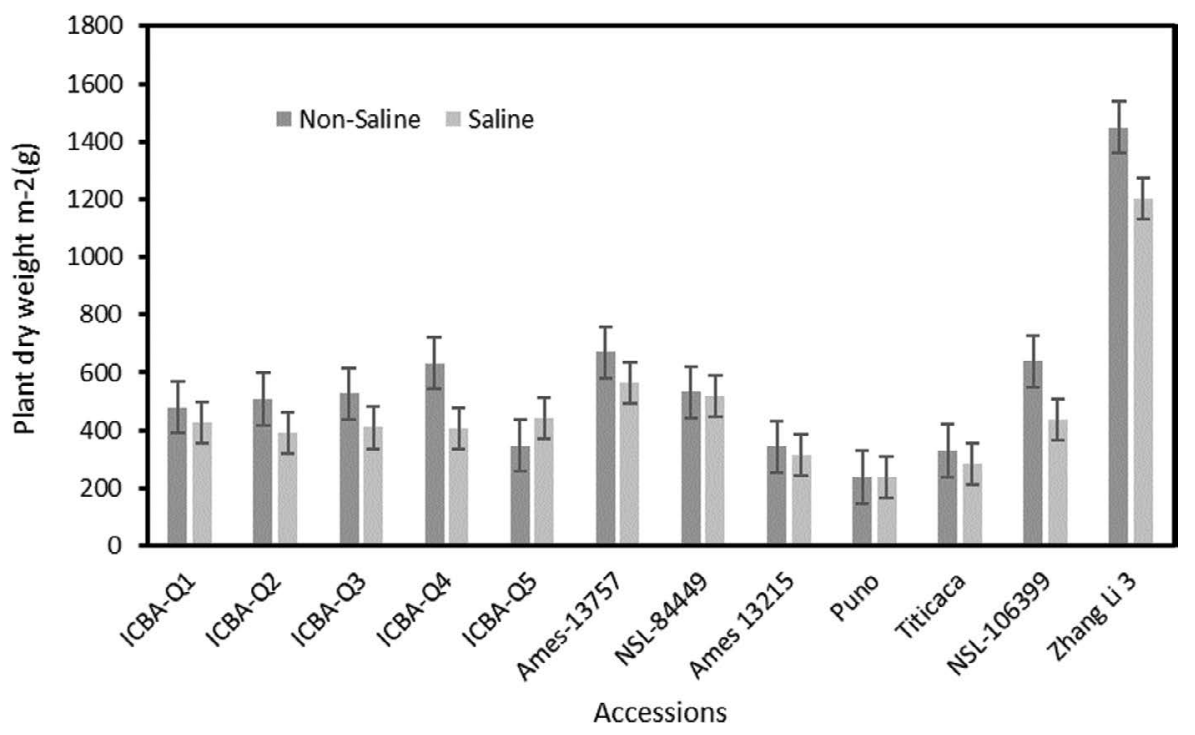

FIGURE 29.8 Plant dry weight of quinoa and djulis accessions at low and high salinities.

and Titicaca with a $44 \%$ reduction was the most affected accession (Figure 29.8). Negative effects of salinity on plant dry matter (15-25\% decreases depending on the salinities of the irrigation waters used) were also noted by Long (2016). Algosaibi et al. (2017) observed similar salinity impacts on quinoa plant dry weight.

\subsubsection{Seed Weight per Square Meter}

Seed yield is the most important trait for the majority of the crops. For quinoa it defines the value of a variety as high yielding varieties are preferred for cultivation. For this key trait, the accessions Ames-13757 and NSL 106399 had highest yields (217 and $208 \mathrm{~g}$ seed $\mathrm{m}^{-2}$, respectively). Ames-13215 had the lowest grain yield (Figure 29.9).

On average, the decline in seed yield in accessions because of high salinity was $25 \%$. The highest decrease was with Puno (50\%) and the lowest decrease was with NSL 84449 (Figure 29.9). Experiments conducted in other places have also shown negative impacts of salinity on seed yield (Long, 2016; Algosaibi et al., 2017; Iqbal et al., 2019).

\subsubsection{Thousand Seed Weight}

One thousand seed weight is an important trait for measuring seed quality; it also plays an important role in germination, seedling development and plant performance (Afshar et al., 2011).

Our study showed variation in this seed trait. Both ICBA Q-2 and ICBA Q-3 had a thousand seed weight of $3.6 \mathrm{~g}$, which was the highest amongst the studied cultivars. The djulis variety Zhang Li 3 had the lowest thousand seed weight (1.1.g) (Figure 29.10). 


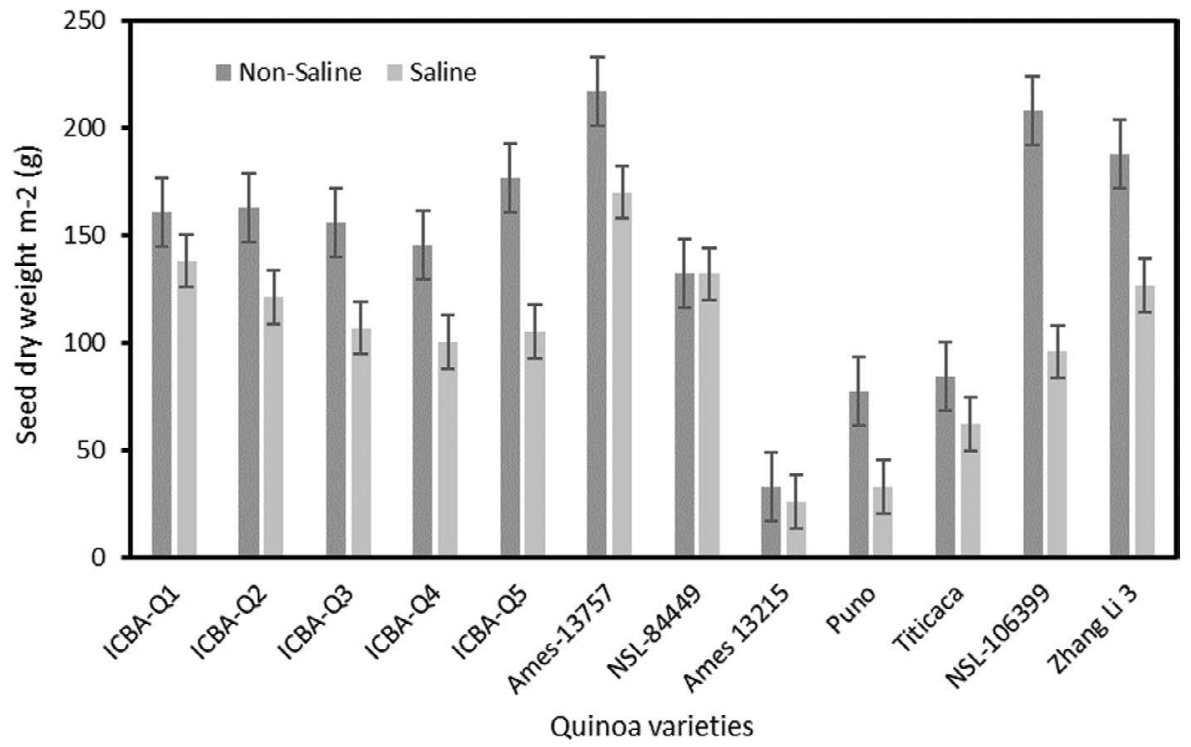

FIGURE 29.9 Seed yield of quinoa and djulis accessions at low and high salinities.

On average, for all accessions salinity decreased thousand seed weight by $7 \%$. Zhang Li 3 didn't show any change in seed weight due to salinity, while other cultivars showed some decline (Figure 29.10). Long (2016) found a sizeable effect of high water-salinities, which decreased the thousand seed weight by $30-40 \%$. While Algosaibi et al. (2017) observed smaller impact of salinity on this seed characteristic.

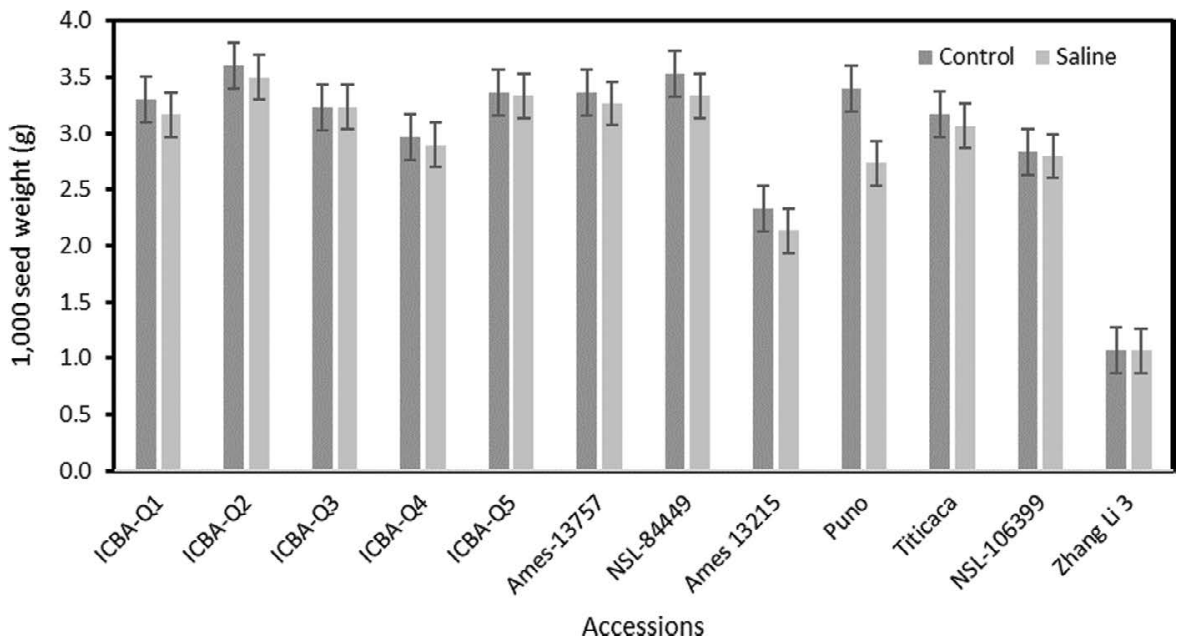

FIGURE 29.10 Thousand seed weight of quinoa and djulis accessions at low and high salinities. 


\subsection{CONCLUSION}

Our results have indicated that at high salinity $\left(\mathrm{EC}_{\mathrm{w}} 15 \mathrm{dS} / \mathrm{m}\right)$, the number of days to flowering and maturity decreased for all the quinoa accessions and the djulis cultivar. The salinity accelerated both flowering and maturity in the studied crops. For these traits, diversity exist in different quinoa cultivars. It was also obvious that salinity had negative effects on plant height, the number of primary branches, the number of panicles, plant dry weight, grain yield and thousand seed weight. Various quinoa accessions reacted differently against high salinity. Based on these results, the identified salt-tolerant quinoa cultivars can be introduced in the marginal lands of different countries with salt-effected large tracts of agricultural lands. High yielding salt-tolerant quinoa varieties will help in improving life in the rural areas of many poor countries, where salinity is affecting the production of other crops. Our study also showed that djulis (Chenopodium formosanum) is a less salttolerant crop in comparison with quinoa (C. quinoa).

\section{REFERENCES}

Adolf, V.I., S. Shabala, M.N. Andersen, F. Razzagh and S.-E. Jacobsen. 2012. Varietal differences of quinoa's tolerance to saline conditions. Plant and Soil 357 (1-2): $117-129$.

Adolf, V. I., S. -E. Jacobsen and S. Shabala. 2013. Salt tolerance mechanisms in quinoa (Chenopodium quinoa Willd.). Environmental and Experimental Botany 92: 43-54. https://doi.org/10.1016/j.envexpbot.2012.07.004.

Afshar, H., M. Eftekhari, M. Faraji, A. G. Ebadi and A. Ghanbarimalidareh. 2011. Studying the effect of 1000 grain weight on the sprouting of different species of Salvia L. growing Iran. Journal of Medicinal Plants Research 5(16): 3991-3993.

Algosaibi, A. M., M. M. El-Garawany, A. E Badran, and A. M. Almadini. 2017. Effect of irrigation water salinity on the growth of quinoa plant seedlings. Journal of Agricultural Science 7(8): 205-214.

Apse, M. P., Aharon, G. S., Snedden, W. A., and Blumwald, E. 1999. Salt tolerance conferred by overexpression of a vacuolar $\mathrm{Na} / \mathrm{H}+$ antiport in Arabidopsis. Science 285: $1256-1258$.

Bhargava A., S. Shukla, S. Rajan and D. Ohri. 2007. Genetic diversity for morphological and quality traits in quinoa (Chenopodium quinoa Willd.) germplasm. Genetic Resources and Crop Evolution 54(1): 167-173.

Blumwald, E., G. S. Aharon and M. P. Apse. 2000. Sodium transport in plant cells. Biochimica et Biophysica Acta-Biomembranes 1465: 140-151.

Choukr-Allah, R., N. K. Rao, A. Hirich, M. Shahid, A. Alshankiti, K. Toderich, S. Gill and K. Butt. 2016. Quinoa for marginal environments: Towards future food and nutritional security in MENA and Central Asia regions. Frontiers in Plant Science 7: 346. doi: 10.3389/fpls.2016.00346.

Curti R. N., A. J. De la Vega, A. J. Andrade, S. J. Bramadi, and H. D. Bertero. 2016 Adaptive responses of quinoa to diverse agro ecological environments along an altitudinal gradient in North West Argentina. Field Crops Research 186: 10-18.

El-Naggar, A. M., S. A. Hussin, E. H. Abd El-Samad and S. S. Eisa. 2018. Quinoa as a new leafy vegetable crop in Egypt. Arab University Journal of Agricultural Sciences 26(2): $745-752$.

Flowers, T. J., M. A. Hajibagheri and N. J. W. Clipson. 1986. Halophytes. Quarterly Review of Biology 61: 313-337. 
Gómez-Pando, L. R., R. Álvarez-Castro and E. de la Barra. 2010. Effect of salt stress on Peruvian germplasm of Chenopodium quinoa Willd: A promising crop. Journal of Agronomy and Crop Science 196, 391-396.

Hariadi, Y., K. Marandon, Y. Tian, S-E. Jacobsen and S. Shabala. 2011. Ionic and osmotic relations in quinoa (Chenopodium quinoa Willd.) plant grown at various salinity levels. Journal of Experimental Botany 62 (1):185-193.

Hasegawa, P. M., R. A. Bressan, J. K. Zhu and H. J. Bohnert. 2000. Plant cellular and molecular responses to high salinity. Annual Review of Plant Biology 51: 463-499.

Hong, Y. H., Huang, Y. L., Liu, Y. C., and Tsai, P. J. 2016. Djulis (Chenopodium formosanum Koidz.) water extract and its bioactive components ameliorate dermal damage in UVBirradiated skin models. BioMed Research International 2016: 7368797. http://dx.doi. org/10.1155/2016/7368797

Iqbal S., S. M. A. Basra, I. Afzal, A. Wahid, M. S. Saddiq, M. B. Hafeez and S.-E. Jacobsen. 2018. Yield potential and salt tolerance of quinoa on salt- degraded soils of Pakistan. Crop Science, 205: 13-21. doi: 10.1111/jac.12290

Jacobsen, S. E., I. Jørgensen, and O. Stølen. 1994. Cultivation of quinoa (Chenopodium quinoa) under temperate climatic conditions in Denmark. Journal of Agriculture Science, 122 (1): 47-52.

Jacobsen, S-E., H. Quispe, H. and A. Mujica. 2001. Quinoa: An alternative crop for saline soils in the Andes, Scientists and Farmer-Partners in Research for the 21st Century. CIP Program Report 1999-2000, pp. 403-408.

Jacobsen, S.-E., Mujica, A. and Jensen, C. R. 2003. The resistance of quinoa (Chenopodium quinoa Willd.) to adverse abiotic factors. Food Reviews International 19 (1 and 2): 99-109.

Jacobsen, S. E., C. Monteros, J. L. Christiansen, L. A. Bravo, L. J. Corcuera, and A. Mujica. 2005. Plant responses of quinoa (Chenopodium quinoa Willd.) to frost at various phonological stages. European Journal of Agronomy 22(2): 131-139.

Kolata, A. L. 2009. Quinoa: Production, Consumption and Social Value in Historical Context, Department of Anthropology, The University of Chicago. Chicago, Ill. USA.

Koyro, H. W., S. S. Eisa, and H. Lieth. 2008. Salt tolerance of Chenopodium quinoa Willd., grains of the Andes: Influence of salinity on biomass production, yield, composition of reserves in the seeds, water and solute relations. Tasks for Vegetation Sciences 43: $133-145$.

Koziol, M. J., 1992. Chemical composition and nutritional evaluation of quinoa (Chenopodium quinoa Willd.). The Journal of Food Composition and Analysis 5: 35-68

L'Avenir Agricole. 2015. Quinoa, une culture à haute valeur ajoutée.

Long, N. V. 2016. Effects of salinity stress on growth and yield of quinoa (Chenopodium quinoa Willd.) at flower initiation stages. Vietnam Journal of Agriculture Science 14: 321-327.

Maughan, P. J., T. B. Turner, C. E. Coleman, D. B. Elzinga, E. N. Jellen, J. A. Morales, J. A. Udall, D. J. Fairbanks, and A. Bonifacio. 2009. Characterization of Salt Overly Sensitive 1 (SOS1) gene homoeologs in quinoa (Chenopodium quinoa Willd.). Genome 52: 647-657.

Mullan, D. J., T. D. Colmer and M. G. Francki. 2007. Arabidopsis-rice-wheat gene orthologues for $\mathrm{Na}+$ transport and transcript analysis in wheat $-L$. elongatum aneuploids under salt stress. Molecular Genetics and Genomics 277: 199-212.

Munns, R. and M. Tester. 2008. Mechanisms of salinity tolerance. Annual Review of Plant Biology, 59: 651-681. https://doi.org/10.1146/annure

Panta, S., T. Flowers, P. Lane, R. Doyle, G. Haros and S. Shabala. 2014. Halophyte agriculture: Success stories. Environmental and Experimental Botany 107: 71-83. https://doi. org/10.1016/j.envexpbot.2014.05.006 
Pathan S., F. Eivazi, B. Valliyodan, K. Paul, G. Ndunguru and K. Clark. 2019. Nutritional composition of the green leaves of quinoa (Chenopodium quinoa Willd.). Journal of Food Research 8 (6): 55-65.

Pickersgill, B. 2007. Domestication of plants in the Americas: Insights from Mendelian and molecular genetics. Annals of Botany 100 (5): 925-940.

Prado, F. E., C. Boero, M. Gallardo, and J. A. González. 2000. Effect of $\mathrm{NaCl}$ on germination, growth, and soluble sugar content in Chenopodium quinoa Willd. seeds. Botanical Bulletin of Academia Sinica 41: 27-34.

Qiu, Q. S., Y. Guo, M. A. Dietrich, K. S. Schumaker, and J. K. Zhu. 2002. Regulation of SOS1, a plasma membrane $\mathrm{Na}+/ \mathrm{H}+$ exchanger in Arabidopsis thaliana, by SOS2 and SOS3. Proceedings of the National Academy of Sciences of the United States of America 99 (12): 8436-8441. http://dx.doi.org/10.1073/pnas.122224699

Ranhotra, G. S. J. A. Gelroth, B. K. Glaser, K. J. Lorenz, K. J. and D. L. Johnson. 1993. Composition and protein nutritional quality of quinoa. Cereal Chemistry 70 (3): 303-305.

Rao, N. K. and M. Shahid. 2012. Quinoa - A promising new crop for the Arabian Peninsula. American-Eurasian Journal of Agricultural \& Environmental Sciences 12: 1350-1355.

Repo-Carrasco, R., C. Espinoza and S.-E. Jacobsen. 2003. Nutritional value and use of the Andean crops quinoa (Chenopodium quinoa) and Ka niwa (Chenopodium pallidicaule). Food Reviews International 19 (1 and 2): 179-189.

Ruiz-Carrasco, K., F. Antognoni, A. K. Coulibaly, S. Lizardi, A. Covarrubias, E. A. Martínez, M. A. Molina-Montenegro, S. Biondi and A. Zurita-Silva. 2011. Variation in salinity tolerance of four lowland genotypes of quinoa (Chenopodium quinoa Willd.) as assessed by growth, physiological traits, and sodium transporter gene expression. Plant Physiology and Biochemistry 49, 1333-1341.

Shabala, S. and A. Mackay. 2011. Ion transport in halophytes. Advances in Botanical Research 57: 151-187.

Singh, D., 2018. Quinoa (Chenopodium Quinoa Willd.). New Delhi, India: Scientific Publishers.

Shahid S. A., A. J. Dakheel, K. S. Mufti and G. Shabbir. 2009. Automated in-situ soil salinity logging in irrigated agriculture. European Journal of Scientific Research 26(2): 288-297.

Soil Survey Staff. 2010. Keys to soil taxonomy, 11th edn. Washington, DC: USDA-NRCS, US. Government Printing Office.

Sosa-Zuniga, V., V. Brito, F. Fuentes and U. Steinfort. 2017. Phenological growth stages of quinoa (Chenopodium quinoa) based on the BBCH scale. Annals of Applied Biology 171: 117-124. https://doi.org/10.1111/aab.12358

Taváres, O. B., M. G. D. Martínez, R. J. L. Ontiveros, and M. A. Orozco. 1995. Forage evaluation of 18 varieties of quinoa (Chenopodium quinoa Willd.) in Montecillo, Mexico. Rev. Fac. Agron. (LUZ), 12 (1): 71-79.

Tsai, P.-J., Y.-S. Chen, C.-H. Sheu and C.-Y. Chen. 2011. Effect of nano grinding on the pigment and bioactivity of djulis (Chenopodium formosanum Koidz.). Journal of Agricultural and Food Chemistry 59(5):1814-1820.

Van Schooten H. A. and J. B. Pinxterhuis. 2003. Quinoa as an alternative forage crop in organic dairy farming. Optimal forage systems for animal production and the environment grassland. Science in Europe 8: 445-448.

Vaughn, J. G. and C. A. Geissler (2009). The new Oxford book of food plants. Oxford, UK: Oxford University Press.

Wilson, C., J. J. Read, and E. Abo-Kassem. 2002. Effect of mixed-salt salinity on growth and ion relations of a quinoa and a wheat variety. Journal of Plant Nutrition 25 (12): 2689-2704. 


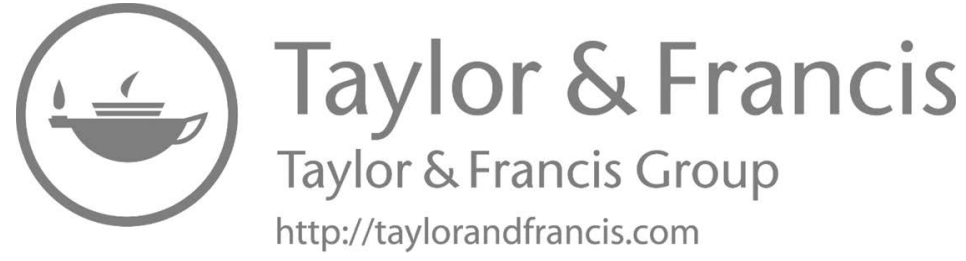

